\title{
Community Perception Surrounding Riung National Park to the Conservation of Komodo Dragon
}

\author{
Willem Amu Blegur ${ }^{*}$, Tjut Sugandawati Djohan², and Su Ritohardoyo ${ }^{3}$ \\ ${ }^{1}$ Faculty of Agriculture, Timor University, Kefamenanu, Indonesia \\ ${ }^{2}$ Faculty of Biology, Gadjah Mada University, Yogyakarta, Indonesia \\ ${ }^{3}$ Faculty of Geography, Gadjah Mada University, Yogyakarta, Indonesia
}

\begin{abstract}
People on Benteng Tengah, Nangamese and Latung have been living in Flores Island and smaller island nearby Flores, like Ontoloe, long before the establishment of national park. In 1992 and 1996, the government established Nature Conservation of Wolo Tado, Nature Conservation of Riung and Marine Nature Conservation of 17 Pulau. This decision led to government's policy to prohibit the opening of land by burning. Local people used to open a land for agricultural purpose by setting a fire in order to regenerate the savanna to promoting the growth of young grass leaves. People use young grass to feed their cattle. This prohibition causes the people had to herd their cattle far from they live. As the consequence, threat from Komodo (Varanus komodoensis) to attack cattle is increased and people consider Komodo as pest that has to be terminated. This research aimed to study people's knowledge about Komodo status as endangered species and its implication. Data were collected from people who lives in Benteng Tengah, Nangamese, and Latung, Regency of Ngada, East Nusa Tenggara. Data were obtained from respondents using interviews and questionnaires. Perception of local people who lives in Benteng Tengah (93\%), Nangamese (93\%) and Latung (100\%) showed that people are aware about Komodo's habitat vegetation. Good perception on Komodo and habitat vegetation will maintain komodo sustainability.
\end{abstract}

Keywords: community perception, fire, Komodo, savanna

\section{Introduction}

Human perception to Komodo (Varanus komodoensis) of East Nusa Tenggara, Indonesia is very important for its sustainability. The more positive of human perception is good for conservation of Komodo. In 1992 and 1996, Main island of Flores and surrounding small island such as Ontoloe island were established as Nature Conservation. The area of Nature Conservation included Nature Conservation of Wolo Tado, Nature Conservation of Riung and Marine Nature Park of 17 Pulau. Since years ago, the people inhabit main island of Flores and lives their daily routine. In Small Island (Ontoloe), people from main island visits occasionally to plant seaweed. They are civilian from Benteng Tengah, Nangamese and Latung. Good knowledge produced good perception and

*Corresponding author:

Willem Amu Blegur

Faculty of Agriculture, Timor University

Jln. Eltari Km. 9, Sasi, Kefamenanu, East Nusa

Tenggara, Indonesia 85613

Email: willemblegur@unimor.ac.id initiated good behavior (Notoadmodjo, 2007; Nasution, 2009) especially to protect Komodo dragon and its habitat vegetation. Perception came from internal and external stimuli directly or indirectly and then influenced one's activities (Walgito, 2009; Sarwono and Meinarno, 2011) in using natural resources, for example the exploitation of mangrove or hunting animals (Pearce and Turner, 1990; Ngakan et al., 2006; Meena et al., 2014). For people whose life is dependent on taking advantage of nature, they would use natural resources wisely, even though when they had to burn savanna on small scale or to hunt animals. Savanna woodland would survive and provide grasses or bushes for livestock and wild animals. It is natural resources for cattle, buffaloes, goats, and deers ( $\mathrm{O}^{\prime}$ Higgins, 2007; Vigilante et al., 2009; Kull and Laris, 2009; Miranda et al., 2009; Sanjay, 2012).

People interacted with wild animals directly or indirectly. Sometimes people hunt them for foods, skins or furs. When wild animals entered inhabited land, people tended to kill them especially 
for animal which disturbed agricultural production, in examples rice, cassavas and vegetables (Graham et al., 2005; Lamarque et al., 2009; Gandiwa et al., 2013; Li et al., 2013; Bekele and Kumssa, 2014; Mojo et al., 2014). To protect wild animals especially threaten animals, the government created conservation areas like national parks. The establishment of national parks separated people with wild animals but people's activities are still connected to wild animals. This establishment are sometimes conducted by converting one's private land status to national park area owned by the government. The area conversion could initiate negative response from society around the area. People felt unpleasant and not allowed to cultivate land inside or near the national park area. They could not plant or herd their cattle or other activities surround it. The prohibition interrupted the welfare of the people (Bitanyi et al., 2012; Gandiwa, 2012; Gandiwa et al., 2013).

In Flores, the conversion of private land to conservation area was decided by Ministry of Forestry, then as a consequence, people are prohibited to burn savanna in this area. This prohibition which was concerned by Balai Konservasi Sumber Daya Alam (BKSDA) Riung disturbed savanna availability in main island Flores. Cervus timorensis lost their food resources especially young grass and young bushes. Varanus komodoensis lost their foods and tended to attack livestock. Then people assumed that Komodo dragon as pest to be hunted or killed.

The objective of this research was to study about people knowledge on Komodo as endangered species which should be protected.

\section{Materials and Methods}

Datacollectionforcommunity perception were conducted using questionnaires and in-depth interview on October 2015. The closed questionnaire provided were multiple choices and should be choose by respondents. They would choose the optional answer about vegetation, damage, and prevention of damage to vegetation of Komodo habitat and sustainability. Open questionnaire were including sex, ages, total member of family, education, basic and side jobs, land status, land use and family income. The main respondent was people who worked as farmers or breeders because their activities are connected to habitat vegetation of Komodo and to Komodo itself. Total respondents that were taken according to quota samples from each study village (Table 1 ).

In-depth interview lists (Table 2) was intended to gain community perception about komodo as endangered species. One of the ways to protect Komodo is by conserving its vegetation habitat by doing small and scheduled burning in savanna to avoid bushes invasion and colonization.

Table 1. Respondents sample for questionnaires

\begin{tabular}{cccc}
\hline Villages & Benteng Tengah & Nangamese & Latung \\
\hline Population & 450 & 412 & 205 \\
Sample & 30 & 30 & 20 \\
\hline Total & \multicolumn{4}{c}{80} \\
\hline
\end{tabular}

Source: BPS Riung, 2014 and primary data

Table 2. Respondents sample for in-depth interview

\begin{tabular}{lccc}
\hline \multirow{2}{*}{ Respondents } & \multicolumn{3}{c}{ Villages } \\
\cline { 2 - 4 } & $\begin{array}{c}\text { Benteng } \\
\text { Tengah }\end{array}$ & Nangamese & Latung \\
\hline Elders & 2 & 2 & 2 \\
Adults & 2 & 2 & 2 \\
Youth & 2 & 2 & 2 \\
SHS Students & 2 & 2 & 2 \\
Village heads & 1 & 1 & 1 \\
BKSDA Riung & 2 & & \\
officers & & & \\
\hline
\end{tabular}

Source: village head of Benteng Tengah, Nangamese and Latung, 2014, primary data

Respondents for in-depth interview were head of village of Benteng Tengah, Nangamese and Latung, two elders (aged up to 65 years old) from every village, two adults from every village, two youth from every village, two students of Senior High School from every village, and 2 persons from BKSDA Riung officer (Table 2).

\section{Data analysis}

Data were analyzed and calculated by giving value for every alternative option, numbering $1-3$. People's choices were 
summed. The results were showed in tables and descriptive analysis was interpreted from those tables. Descriptive analysis for community perception would investigate the influenced of sex, ages, education background, farming, and husbandry activities and income of the people who lives in main island Flores and small island,

Ontoloe. Interval values from every criterion were calculated using category scale or interval (I), with formula as follows:

\section{$I=\underline{\text { Upper total score }- \text { Lowest total score }}$}

\section{Results}
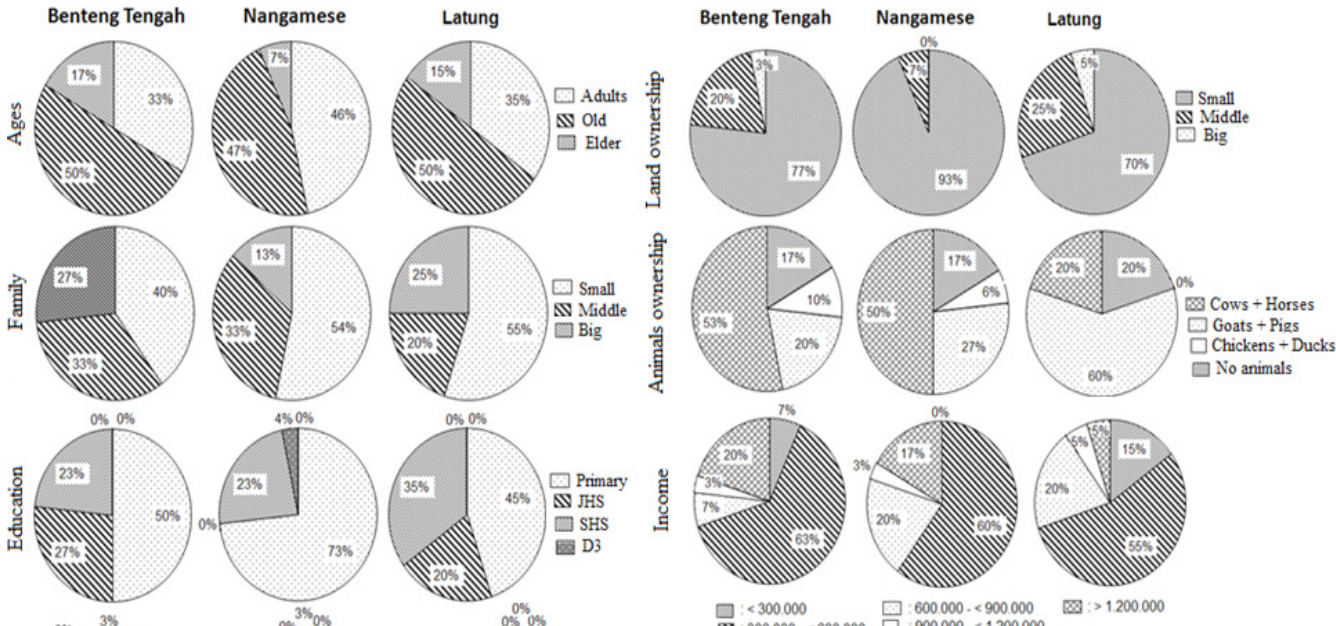

KN $: 300.000<600.000 \quad 9000.000<1.200 .000$
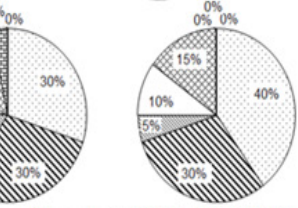

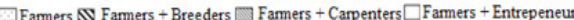

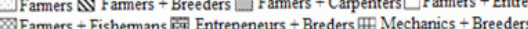
$\mathrm{B}$ Famers + Fishemans
$\mathrm{Q}$ Civil servants + Breders

Figure 1. Social data of Benteng Tengah, Nangamese and Latung. Data were collected by purposive random sampling to males as farmer or breeder.
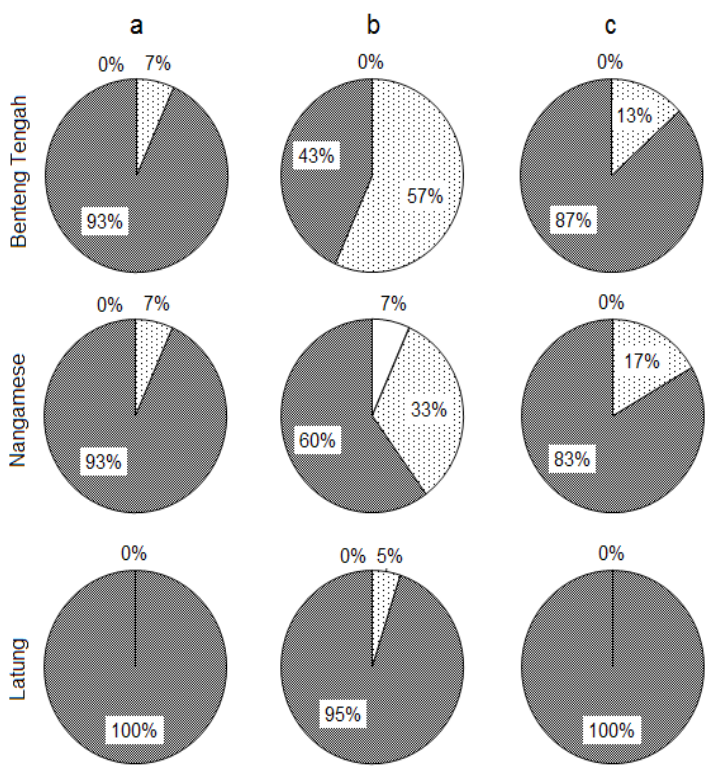

Figure 2. People's knowledge and perception to: a). Komodo and habitat vegetation; b). Threaten of komodo and vegetation habitat; c). Avoidance to threaten of a komodo and vegetation habitat. Legend: clear $=$ Low, dotted $=$ Middle, dark $=$ High . 


\section{Discussion}

The community perception of Komodo influenced behavior the people whose lived there as local people to protect it. People in the research site participate to protect Komodo by efforts to avoid threat to vegetation habitat of Komodo.

\section{Social Community and Perspective to Komodo}

People from Benteng Tengah, Nangamese, and Latung had good knowledge and perception about Komodo and vegetation habitat of Komodo (Figure 2: $93 \%, 93 \%, 100 \%)$. Education level of primary school dominated in three study areas (Figure 1: $50 \%, 73 \%$, and $45 \%$ ), but education level did not influence the community perception about Komodo and its vegetation habitat. Result from questionnaires and in-depth interviews showed that old people (Figure 2: $50 \%, 47 \%$, and $50 \%$ ) felt comfortable about the existence of Komodo. It is an icon of Riung town and East Nusa Tenggara province. Similar respond showed by youths and students of Senior High School. But for people who basically worked as farmers and sometimes went to herd their cattles or as breeders and carpenter worried about the presence of Komodo (30\%). Even though sometimes they met Komodo and had positive perception about it, the hesitation rose because of prohibition to burn savanna even on small scale.

People who had land less than 2 ha (Figure 1) in Benteng Tengah (77\%), Nangamese (93\%), and Latung (70\%) did another activities to increase their welfare. The alternative option is husbandry. People from Benteng Tengah and Nangamese had large animals like cattle and horses (53\% and 50\%). In Latung, people had medium size of animals like goats and pigs $(60 \%)$. They usually sell the animals to increase their income.

The family with more family members at home would support their daily activities. Small family with less than 5 persons are dominant in Latung (55\%), Nangamese (54\%) and Benteng Tengah (40\%), respectively. These types of family initiated young men to find any jobs in surrounding town, such as Bajawa and Nangapenda. In addition, some students moved to city to get higher education. These phenomenon influenced daily habits to impart knowledge from old generation to next-generation especially the knowledge about Komodo.

People's welfare is one stimulus that influenced community perception about Komodo. As mentioned before that farming is a common work for these people, therefore, it influenced the monthly income. People from these three villages Benteng Tengah (63\%), Nangamese $(60 \%)$, and Latung (55\%) were predominantly had lower monthly income: Rp 300.000 - Rp 600.000. The people get salary by selling agricultural products like vegetables, corn, candlenuts, and coconuts. Husbandry is an alternative source of money, therefore savanna woodland availability in their living area is very important.

\section{The Community and Rusa Timor}

The presence of Rusa Timor (Cervus timorensis) did not disturb agricultural farming of the community. The meat of $C$. timorensis as wild animal was one of the protein sources for the community. Hunting might be following the rule of indigenous hunting. Indigenous hunting is held every year at the end of August. Before doing it, people performed traditional celebration as a indication of early farming activities. When the research data was collected, deer population has decreased $40 \%$.

\section{Relation among Komodo, Wild Animals and Vegetation}

The perception about threats to Komodo and its habitat vegetation in Benteng Tengah, Nangamese and Latung are middle to high (Figure 2; 57\%, 60\% and 95\%). The character of the Komodo in main island Flores and small island Ontoloe are cautious and wild. They run whenever met people on their area. It is different with komodo in Labuan Bajo which is more benign to humans (Jessop et al., 2006); Ciofi and de Boer (2004) stated that they did not get any Komodo in their traps after investigation in mangrove in Padar Island. But, sometimes people in Benteng Tengah, Nangamese and Latung saw it in 
mangrove area and savanna woodland. They understand that Komodo is in danger.

The existence of Komodo are supported by the presence of deer wild goats, wild cattle, and wild buffaloes as their prey. Their life was influenced by savanna woodland availability. As we explained before, savanna regeneration and availability are initiated by fire on a small scale in Flores. Young grasses and young bushes, such as $H$. contortus is important diet for deer (Ginantra et al., 2014). Observation in Ontoloe showed that Komodo eat bats like Cynopterus sp. They need branches of $R$. mucronata to hang it on. In Flores island, deer find fresh water by moving into mangrove ecosystem especially in dry season. In rainy season, they could drink water in legong forest ecosystem (Ginantra et al., 2014). Deer usually take cover under canopy of trees as we found dungs inside canopy area. People did not cut down trees frequently both in Flores and Ontoloe islands. Some people take couple of tree branches for using it in their houses as firewood or to build their houses. They usually choose stems of S. ovata.

\section{The Usage of Savanna Woodland by the People}

People understanding about vegetation usage as a source of prey of komodo and shading is high. Questionnaires results (Figure 2) to respondents in Benteng Tengah, Nangamese and Latung indicated high knowledge and good perception in community. In-depth interview results from group of head villages, elders, farmers, breeders, fishermen, and students of Senior High School were the same. People's understanding initiated a good perception of Komodo and its vegetation habitat.

Ritohardoyo (2005), stated that positive knowledge in the community is support good perception and initiate a better behavior in using resources. Local people thought that Komodo is an asset for them to be protected. In fact, there are conflicts among people as breeder with Komodo and people with BKSDA Riung officers. Komodo attacked cow and goat while roamed in their surrounding area. Komodo lost their food because no deer are available. Deer are vanished because no young grass and young bushes availability in savanna woodland. People took trees in a small portion because they use for household needs only (Wahyuni and Mamonto, 2012). They did not clear the area by cutting down the trees. To them whose owned agricultural land, cutting and clearing land is always continued by small scale of burning. It is the fastest way to open the land. Agricultural waste is also faster to be decomposed by the small scale of burning.

\section{Fire on Savanna Woodland}

The culprit who burn savanna woodland is not recognized yet both by BKSDA Riung officers and indigenous people. There are two types of fire culprits. The first type is a person who was unpurposive in burning, like deliberately cigarette fire left over to savanna. The second type is purposive person. Some of them are breeder or herder, they burned savanna to provide young grass and young bushes to their livestock. BKSDA Riung officer stated that they have done some socialization to these local breeder/herder. They necessitated to the breeders and farmers to provide fire brigade when they burn their savanna woodland. It would help to stop fire for spreading to other areas. But the information regarding the socialization from BKSDA is denied by local people. According to the local people, there are no socialization by BKSDA Riung. This communication problem generated conflict between people who works as farmers and breeders with BKSDA Riung offices.

A few years ago, indigenous people were collaborated to extinguish the fire with BKSDA Riung officers voluntarily. People whom ever felt harm by the fire were concerned with extinguishing fire because they got "benefits" of it. (Gan et al., 2015). But for people who need to use the fire for new grass resources will let the fire on and tend to be passive with the fire in savanna woodland.

Indigenous people have traditional rights admitted by the Rio Convention in 1992 and in article 18B of constituent 1945 of Republic of Indonesia. Giving traditional rights to indigenous people to manage the 
forest by conducting small scale of burning is reasonable. These habits would maintain savanna availability in Flores island, but not in Ontoloe island. Once again, there is no grassland for deer (Ginantra et al., 2014), cattle, goats and buffaloes disturbed by fire in Ontoloe Island. When it happened, komodo dragon will lost their food resources.

\section{Threats Prevention of Komodo and Vegetation Habitat}

The people in Benteng Tengah, Nangamese, and Latung understand that they must prevent any threat to Komodo and its habitat vegetation $(87 \%, 83 \%$, and $100 \%)$. They know that without any protection, Komodo will be extincted from Flores and Ontoloe Island. As we explained before, burning habits will maintain savanna availability, it would maintain grasses and bushes for Komodo's prey include deer, cattle and goats. A few years ago, some people voluntarily provided goats and chicken meat for Komodo, but, they lacked of fund so it was discontinued. When BKSDA Riung prohibited small burning in savanna in Flores Island, it would disturb savanna. Komodo dragon tend to attack livestock animals. For people who experiencing attacked by Komodo, they assumed it as pest and supposed to be hunted or killed (Inskip et al., 2014). But for those who care about it will protect them. In 2005, there were some people who brought back Komodo to BKSDA Riung to be identified dan saved before have released to nature.

\section{Conclusion}

People are aware to protect Komodo as endemic and endangered species, not only in Riung but all around the world. The community in Riung region has various background that influencing their perception on Komodo (Varanus komodeonsis). People in Latung show the highest positive community perception on Komodo and habitat vegetation (100\%) but at Benteng Tengah and Nangamese $93 \%$. Peoples from these villages are participated indirectly to join in Komodo protection action by small burning in savanna woodland. They don't know that small burning will help to maintain savanna woodland regeneration and sustainability. It is done deliberately to provide food for their livestock. After that Komodo prey will available. Then komodo existence will sustain.

\section{Acknowledgement}

We thank to officers from BKSDA Riung for permission and helping in data collection; Achmad Arifiendy from Komodo Survival Program for funding and discussion; Krisni from Faculty of Biology UGM for ideas; Father Meo and family for kindness when I took the data.

\section{References}

Bekele, A \& T. Kumssa. (2014). Attitude and Perceptions of Local Resident toward the Protected Area of Abija-Shalla Lakes National Park (ASLNP), Ethiopia. Ecosystem and Ecography, 1(4), 1-5.

Bitanyi, S. M., Nesje, L. J. M., Kusiluka, S. W. Chenyambuga, \& B. P. Kaltenborn. (2012). Awareness and perception of local people about wildlife hunting in western Serengiti communities. Tropical Conservation Science, 2(5), 208-224.

Ciofi, C., \& M. E. de Boer. (2004). Distribution and Conservation of the Komodo Monitor (Varanus komodoensis). Herpetological, 14, 99 - 107.

Gan, J., A. Jarret, \& C. J. Gaither. (2015). Landowner response to wildlife risk: Adaptation, mitigation or doing nothing. Journal of Environmental Management, 159, 186 - 191.

Gandiwa, E. (2012). Local knowledge and perception of animal population abundances by communities adjacent to the northern Gonarezhou National Park, Zimbabwe. Tropical Conservation Science, 3(5), 255-269.

Gandiwa, E., I. M. A. Heitkönig., A. M. Lokhorst., H. H. T. Prins, \& C. Leeuwis. (2013). CAMPFIRE and HumanWildlife Conflict in Local Communities Bordering Northern Gonarezhou National Park, Zimbabwe. Ecology dan Society, 18(4), 7-22.

Ginantra, K., S. Putra, W. Suarna, \& W. Kasa. (2014). Botanical Composition of 
forage by Timor Deer (Cerous timorensis Blainville) in A Monsoon Forest and Savanna of West Bali National Park. International Journal of Pure $\mathcal{E}$ Applied Bioscience, 2(5), 205-213.

Graham, K., A. P. Beckerman, \&S. Thirgood. (2005). Human-predator-prey conflicts: ecological correlates, prey losses, and patterns of management. Biological Conservation, 122, 159-171.

Inskip, C., Z. Fahad, R. Tully, T. Roberts, \& D. MacMillan. (2014). Understanding carnivore killing behavior: Exploring the motivations for killing the tiger in the Sundarbans, Bangladesh. Biological Conservation, 180, 42-50.

Jessop, T.S., T. Madsen, J. Sumner. H. Rudiharto, J.A. Philips, \& C. Ciofi. (2006). Maximum body size among insular Komodo dragon populations covaries with large prey density. OIKOS, 112, 422 - 429.

Kull, C.A \& P. Laris. (2009). Fire ecology and fire politics in Mali and Madagaskar. Springer, 7, 171-226.

Lamarque, F., J. Anderson., R. Fergusson., M. Lagrange., Y. Osei-Owusu, \& L. Baker. (2009). Human-wildlife conflict in Africa: Causes, consequences, and management strategies. Roma. Food and Agriculture Organization of the United Nations.

Li, J., H. Yin., D. Wang., Z. Jiagong, \& Z. Lu. (2013). Human-snow leopard conflict in the Sanjiangyuan Region on the Tibetann Plateau. Biological Conservation, 166, 116-123.

Meena, V., D. W. Macdonald, \& R. A. Montgomery. (2014). Managing success: Asiatic lion conservation, interface problems and peoples' perception in the Gir Protected Area. Biological Conservation, 174, 120-126.

Miranda, H. S., M. N. Sato., W. N. Neto, \& F. S. Aires. (2009). Fires in the cerrado, the Brazilian savanna. Springer, 15, 427-450.

Mojo, D., J. Rothschuh, \& M. Alebachew. (2014). Farmers' perception of the impacts of human-wildlife conflict on their livelihood and natural resource management efforts in Cheha Woreda of Guraghe Zone, Ethiopia. HumanWildlife Interaction, 8(1), 67-77.

Nasution, Z. (2009). Solidaritas Sosial dan Partisipasi Masyarakat Desa Transisi: Suatu Tinjauan Sosiologis. Malang. UMM Press.

Ngakan, P. O., H. Komarudin., A. Achmad., Wahyudi, \& A. Tako. (2006). Ketergantungan, Persepsi dan Partisipasi Masyarakat terhadap Sumberdaya Hayati Hutan, Studi Kasus di Dusun Pampli Kabupaten Luwu Utara, Sulawesi Selatan. Jakarta: Centre for International Forestry Research.

Notoadmodjo, S. (2007). Promosi Kesehatan dan Ilmu Perilaku. Jakarta: Penerbit PT Rineke Cipta.

O'Higgins, R. C. (2007). Savanna Woodland Degradation Assessment in Ghana: integrating ecological indicators with local perceptions. Earth E Environment, 3, 246-281.

Pearce, D. W \& R. K. Turner. (1990). Economics of Natural Resources and the Environment. Hertfordshire: Harvester Wheatsheaf.

Ritohardoyo, Su. (2005). Pengelolaan dan Pemetaan Potensi Hutan Mangrove di Pesisir Utara Pulau Sumbawa. Laporan Penelitian. Yogyakarta: Fakultas Geografi UGM.

Sanjay, G. (2012). Patterns and correlates of human-elephant conflict around a south Indian reserve. Biological Conservation, 148, 88-95.

Sarwono, S.W \& Eko A. Meinarno. (2011). Psikologi Sosial. Jakarta: Penerbit Salemba Humanika.

Vigilante, T., B. P. Murphy, \& D. M. J. S. Bowman. (2009). Aboriginal fire use in Australian tropical savannas: Ecological effects and management lesson. Springer, 6, 143-167.

Wahyuni, N. I., dan R. Mamonto. (2012). Persepsi Masyarakat terhadap Taman Nasional dan Sumberdaya Hutan: Studi Kasus Blok Aketawaje, Taman Nasional Aketawaje Lolobata. Info BPK Manado, 2(1), 1-16.

Walgito, B., (2009). Psikologi Sosial: Suatu Pengantar. Yogyakarta: Penerbit ANDI. 